\title{
Correction to: Cancer cases detected in the prevention and control service of a private cancer clinic in Peru
}

José Revilla-López ${ }^{1 \dagger}$, Andrea Anampa-Guzmán ${ }^{2^{*}}$, Luis Casanova Marquez ${ }^{3}$, Katrina Weeks ${ }^{4}$, Suzanne Pollard ${ }^{4}$, Adriel Olórtegui-Yzú ${ }^{5}$, María Ruiz-Velazco ${ }^{1}$, Alba Davila-Edquen ${ }^{1}$, Daniel Castro-Dorer ${ }^{1}$, Juan Wong-Barrenechea ${ }^{1}$, Jossira Abad-Seminario ${ }^{1}$, Pamela Gonzáles-Ramos ${ }^{1}$, Fiorella Rivera-Sandoval ${ }^{1}$ and Carlos Carracedo-Gonzáles ${ }^{6}$

\section{Correction to: Infect Agents Cancer \\ https://doi.org/10.1186/s13027-019-0259-0}

In the original publication of this article [1] several figures and tables were incorrectly displayed. In this correction article the correct overview of the tables and figures are published. The original article has been updated. The publisher apologizes to the readers \& authors for the inconvenience.

Table 1 Packages for women

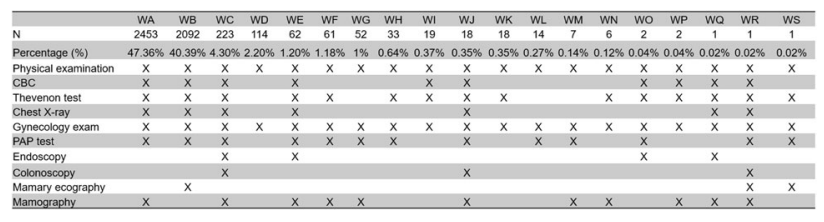

Table 2 Packages for men

\begin{tabular}{|c|c|c|c|c|c|c|c|c|c|c|}
\hline & MA & MB & MC & MD & ME & MF & MG & MH & MI & MJ \\
\hline $\mathrm{N}$ & 1111 & 1072 & 102 & 59 & 43 & 32 & 22 & 22 & 9 & 1 \\
\hline Percentage $(\%)$ & $44.93 \%$ & $43.34 \%$ & $4.12 \%$ & $2.39 \%$ & $1.74 \%$ & $1.29 \%$ & $0.89 \%$ & $0.89 \%$ & $0.36 \%$ & $0.04 \%$ \\
\hline Physical examination & $\mathrm{x}$ & $x$ & $x$ & $x$ & $x$ & $\mathrm{x}$ & $\mathrm{x}$ & $x$ & $x$ & $x$ \\
\hline & $\hat{x}$ & $\hat{x}$ & $\hat{x}$ & & & $\hat{x}$ & $\hat{x}$ & & & $\hat{x}$ \\
\hline Thevenon test & $\mathrm{x}$ & $\mathrm{x}$ & $x$ & & $x$ & $x$ & $\mathrm{x}$ & $x$ & & $x$ \\
\hline Chest X-ray & $x$ & $x$ & $x$ & & & $x$ & $x$ & & & $\mathrm{x}$ \\
\hline Urologic exam & $x$ & $x$ & $x$ & $x$ & $x$ & $x$ & $x$ & $\mathrm{x}$ & $x$ & $\mathrm{x}$ \\
\hline Endoscopy & & & $x$ & & & $x$ & & & & $x$ \\
\hline Colonoscopy & & & $\mathrm{x}$ & & & & $x$ & & & $\mathrm{x}$ \\
\hline PSA test & $\mathrm{x}$ & & $\mathrm{x}$ & & $x$ & $\mathrm{x}$ & $\mathrm{x}$ & & $x$ & \\
\hline
\end{tabular}

The original article can be found online at https://doi.org/10.1186/s13027019-0259-0

* Correspondence: andrea.anampa@outlook.com.pe

†José Revilla-López and Andrea Anampa-Guzmán contributed equally to this work.

${ }^{2}$ Faculty of Medicine, Universidad Nacional Mayor de San Marcos, Lima, Peru Full list of author information is available at the end of the article
Figure 1 Cancer Screening Algorithm for Cancer Prevention and Control Service at ALIADA

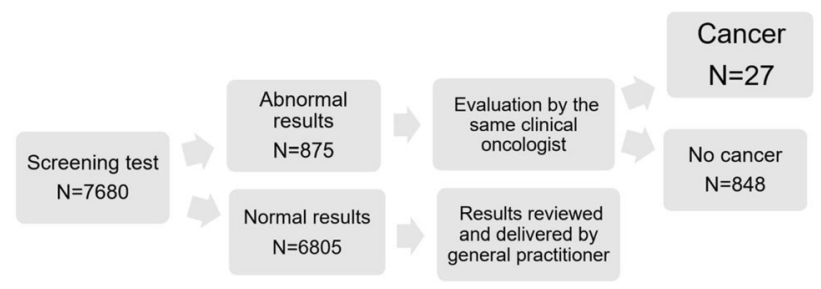

\section{Author details}

${ }^{1}$ Cancer Prevention and Control Service, ALIADA Contra el Cáncer, Lima, Peru. ${ }^{2}$ Faculty of Medicine, Universidad Nacional Mayor de San Marcos, Lima, Peru. ${ }^{3}$ Deparment of Medical Oncology, ALIADA contra el cáncer, Lima, Peru. ${ }^{4}$ Department of International Health, Bloomberg School of Public Health, Johns Hopkins University, Baltimore, USA. ${ }^{5}$ Department of Preventive Medicine and Public Health, Universidad Nacional Mayor de San Marcos, Lima, Peru. ${ }^{6}$ General Medical Council, ALIADA Contra el Cáncer, Lima, Peru.

Published online: 19 December 2019

\section{Reference}

1. Revilla-López J, Anampa-Guzmán A, Marquez LC, et al. Cancer cases detected in the prevention and control service of a private cancer clinic in Peru. Infect Agents Cancer. 2019;14:44. https://doi.org/10.1186/s13027-019-0259-0.

(c) The Author(s). 2019 Open Access This article is distributed under the terms of the Creative Commons Attribution 4.0 International License (http://creativecommons.org/licenses/by/4.0/), which permits unrestricted use, distribution, and reproduction in any medium, provided you give appropriate credit to the original author(s) and the source, provide a link to the Creative Commons license, and indicate if changes were made. The Creative Commons Public Domain Dedication waiver (http://creativecommons.org/publicdomain/zero/1.0/) applies to the data made available in this article, unless otherwise stated. 